Bond University

Research Repository

\title{
Size and book-to-market factors in Australia
}

Brailsford, Tim; Gaunt, Clive; O'Brien, Michael A.

Published in:

Australian Journal of Management

DOI:

$10.1177 / 0312896211423555$

Licence:

Unspecified

Link to output in Bond University research repository.

Recommended citation(APA):

Brailsford, T., Gaunt, C., \& O'Brien, M. A. (2012). Size and book-to-market factors in Australia. Australian Journal of Management, 37(2), 261-281. https://doi.org/10.1177/0312896211423555

\section{General rights}

Copyright and moral rights for the publications made accessible in the public portal are retained by the authors and/or other copyright owners and it is a condition of accessing publications that users recognise and abide by the legal requirements associated with these rights.

For more information, or if you believe that this document breaches copyright, please contact the Bond University research repository coordinator. 


\section{Bond University}

\section{ePublications@bond}

Speeches, addresses, articles

Chancellory

4-26-2012

\section{Size and book-to-market factors in Australia}

Tim Brailsford

Bond University, tim_brailsford@bond.edu.au

Clive Gaunt

University of Queensland

Michael A. O'Brien

Schroders Investment Management

Follow this and additional works at: http://epublications.bond.edu.au/chanc_pubs

Part of the Business Commons

\section{Recommended Citation}

Tim Brailsford, Clive Gaunt, and Michael A. O'Brien. (2012) "Size and book-to-market factors in Australia" Australian journal of management, (Online first), 1-22: ISSN 0312-8962.

http://epublications.bond.edu.au/chanc_pubs/4 


\title{
Size and Book-to-market Factors in Australia
}

\author{
Tim Brailsford* \\ Clive Gaunt ${ }^{\wedge}$ \\ Michael A. O'Brien" \\ *Bond University \\ Gold Coast, Australia 4229 \\ ${ }^{\wedge}$ UQ Business School \\ The University of Queensland \\ Australia, 4072 \\ ${ }^{\#}$ Schroders Investment Management \\ Sydney, Australia, 2000
}

\section{Abstract}

There is continuing debate in the asset pricing literature as to the acceptance of the Fama-French threefactor model. While this model has received strong empirical support from tests in the US equity market, tests of the model in the Australian market have yielded inconclusive findings, particularly in respect of the HML factor. Prior research in Australia has suffered from limited datasets in respect of the accounting variables, and previous results vary with the scope of the dataset employed. Our study provides two advances. First, the study utilises a purpose-built dataset spanning 25 years and $98 \%$ of all listed firms. Second, the study employs a more appropriate portfolio construction method than that employed in prior studies. With these advances, the study is more able to test the three-factor model against the CAPM. The findings support the superiority of the Fama-French model, and for the first time align the research in this area between Australia and the USA.

JEL Classification: G110, G120, G140

Keywords: Size effect; Book-to-market effect; CAPM; Asset pricing; Fama-French Three-Factor Model

\section{Acknowledgments}

The authors gratefully acknowledge financial assistance provided by Dimensional Fund Advisors (DFA) Australia. The paper forms part of a larger project undertaken collaboratively with Monash University and DFA Australia, and has been adapted from research presented in Michael O'Brien's doctoral thesis undertaken at the University of Queensland. The authors thank Joey Low and Daniel Chai for assistance with the database. 


\section{Introduction}

One of the most debated topics in the financial literature concerns the determinants of share price movements. The literature has developed from single-factor models through to multi-factor models. The seminal work of Fama \& French (1992) moved the debate to a focus on several key factors including size and book-to-market.

Prior research in the area has largely been limited to the US market partly because of the essential requirements of a comprehensive and accurate database covering both equity prices and company-specific financial information. While there has been some prior research using Australian data, this has been limited in depth and time series coverage by the availability of accounting data.

While several previous studies have attempted to test the three-factor model in Australia, the results have been mixed and generally weak compared to the US findings. For instance, Halliwell, Heaney \& Sawicki (1999) test the three-factor model using data from the 1980s while Durack, Durand \& Maller (2004), Gaunt (2004), Gharghori, Chan \& Faff (2006, 2007), and Faff (2001, 2004) study the three-factor model using data from the 1990s. These studies find that the three-factor model explain returns better than the traditional CAPM, but the results are far from conclusive. As an example, evidence suggests that the SMB factor is the main explanatory variable in Australia, however in some studies it has a negative sign, while in others it has a positive sign. These inconsistent results have been documented over similar time periods. Further, the findings tend to indicate weak premiums, although the studies by Gharghori, Chan \& Faff $(2006,2007)$ indicate that when a larger proportion of stocks are included the HML premium is positive and significant. 
It is possible that these inconsistent results are, at least partly, the product of the short time-periods and the limited coverage of stocks due to a lack of financial accounting data required to construct the book-tomarket factors. For instance, Halliwell, Heaney \& Sawicki (1999) had access to approximately $26 \%$ of the total number of companies that were listed during the 1980s, while Gaunt (2004) and Gharghori, Stryjkowski \& Veeraraghavan (2007) had access to less than 50\% of the total number of companies listed during the 1990 s.

More recently, Brailsford, Gaunt and O'Brien (2011) have recently demonstrated that these prior results are likely to be affected by the portfolio construction employed. They suggest an alternative approach more consistent with that used in the research into the US market. Accordingly, this alternative approach is employed here.

This study presents the first comprehensive examination of the Fama-French factors in the Australian market both in terms of time-series and cross-section. Using source data from the Australian Stock Exchange and collected annual reports, a database is constructed comprising more than $98 \%$ of all listed Australian companies. The sample is constructed over a 25-year period from 1982 to 2006. Hence, the study provides a strong out-of-sample test of the model, directly addressing the criticism of data snooping.

\section{Prior Research}

The seminal work by Fama \& French (1992) posited that other factors beyond systematic risk were capable of explaining variation in equity returns. By forming portfolios based on various characteristics, Fama \& French were able to analyse the influence and association of key attributes on portfolio returns. That study 
noted a number of factors but two that have become generally accepted and used in a pricing sense are size and book-to-market.

The relationship between size and equity returns is well established and documented. Banz (1981) was among the first to document an inverse relationship between the market value of equity and returns. In particular, returns to the smallest sized portfolios significantly outperform returns on the largest size portfolios. A similar finding has since been documented beyond the U.S., including in Australia. Beedles, Dodd \& Officer (1988) show that the size premium in Australia is even more pronounced when portfolios are formed on the basis of deciles. This difference between returns on the small and large portfolios has now become the basis for one of the factors underlying the Fama-French three-factor model.

In addition to beta and size, Fama \& French (1992) introduce book-to-market ratios as a distinguishing characteristic. Specifically, Fama \& French show that portfolios formed on the basis of ranked book-tomarket ratios exhibit differential performance. Portfolios comprising firms with high book-to-market ratios out-perform portfolios that comprise firms with low book-to-market ratios. This has become known as the value-growth premium.

Fama \& French (1993) argue that these variables (size, book-to-market) can be construed as pricing factors. While this claim has been criticized because of the lack of real theoretical justification, nonetheless it has led to tests of a pricing model using mimicking portfolios formed by ranking all available shares according to the particular variable of interest. The premium is then proxied by taking the difference in returns between the extreme portfolios. 
Successive studies have confirmed the relevance of size and book-to-market factors in the US equity market. Despite continued criticism concerning the lack of a theoretical foundation (eg. Brennan, Wang \& Xia, 2004; Daniel \& Titman, 1997; Daniel, Titman, \& Wei, 2001; Lakonishok, Shleifer, \& Vishny, 1994; LaPorta, et al. 1997; Petkova 2006) and criticisms over data snooping (eg. Black, 1993a, b; Haugen and Baker, 1996; Kothari, Shanken, \& Sloan, 1995), the evidence continues to support the existence of these factors as being relevant to explaining variations in returns (eg. Barber and Lyon, 1997; Davis, Fama \& French, 2000; Fama \& French, 1996, 2006, Griffin, 2002).

Studies in international markets have been harder to conduct as reliable data, especially on book values over a long time-series are generally not available. Nevertheless, examples such as Chui and Wei (1998) in the Asia-Pacific region have been in general accord with the US results.

In Australia, there have been several attempts to test the Fama-French framework. Halliwell, Heaney \& Sawicki (1999) represent one of the early attempts. As noted above, their sample was limited to only around one-quarter of listed firms with a bias to large firms. Their results generally fail to support a value-growth premium. Faff (2001) attempts to overcome the difficulties in constructing a value-growth factor by employing style indices produced for the purposes of benchmarking fund manager performance. However, even these indices contain a bias as they are based on the largest 200-300 listed stocks.

More recently, Durand, Limkriangkrai \& Smith (2006), Gaunt (2004) and Gharghori, Chan \& Faff (2006, 2007) study whether the three factor model can explain portfolio returns since the mid 1990's. As noted above these studies had access to a limited number of companies, which caused a bias to large established firms. These studies find that the SMB factor is significant in explaining portfolio returns. In contrast, there 
is mixed support for the HML factor being significant, although the studies which include a larger proportion of firms, find a positive and significant HML premium. These inconclusive results on the HML factor led Durack, Durand \& Maller (2004) to suggest that further research is required on the book to market anomaly in Australia.

In a recent study, Brailsford, Gaunt and O'Brien (2011) draw attention to the portfolio construction method employed in prior Australian studies. They show how it is critically different to that employed in the US market. The paper documents that the average stock profile in the constructed portfolios is markedly different from those in the US market. In particular, the skew in the Australian market means that prior studies utilize portfolios that have a much larger proportion of total market capitalization assigned to the largest size quintile and a significantly smaller proportion in the smallest size quintile. While prior Australian studies generally do not find evidence of a value premium, when Brailsford et al. (2011) employ a portfolio construction method which parallels the standard US approach, a value premium is clearly apparent.

In summary, the Fama-French model is yet to be fully tested in the Australian market because of the ongoing problems associated with constructing mimicking portfolios that are truly representative of all stocks in the market. Further, prior Australian studies employ a portfolio construction method which is not comparable with prior US research. The consequently mixed and inconclusive findings from previous Australian studies leave a confusing picture for those interested in a deeper understanding of how the Australian market prices risky assets. 
This study employs a new purpose-built dataset that comprises almost complete coverage of the Australian market over a twenty-five year period. The dataset is constructed from source documents covering over $98 \%$ of all listed firms. This study also employs an alternative portfolio construction method suggested by Brailsford et al. (2011) to ensure comparability with US research. The subsequent analysis in this study focuses on both the cross-sectional and time-series attributes of the constructed factors.

\section{Testing Framework}

\subsection{Time-Series Framework}

Empirically, the CAPM proposes that the variation of asset returns should be explained by the assets loading on the market risk premium. This can be expressed as:

$$
r_{i t}=\alpha_{i}+\beta_{i} M R P_{t}+\varepsilon_{i t} \quad i=1, \ldots, N .
$$

where $r_{i t}$ is the excess return on asset $i$ in time $t . M R P_{t}$ is the excess return of the market in time $t . \alpha_{i}$ and $\beta_{i}$, are regression coefficients, $\varepsilon_{i t}$, are the error terms and $N$ is the number of test assets.

Similarly the Fama and French three factor model can be expressed as:

$r_{i t}=\alpha_{i}+\beta_{i} M R P_{t}+s_{i} S M B_{i t}+h_{i} H M L_{i t}+e_{i t} \quad i=1, \ldots, N$.

where $r_{i t}, M R P_{t}$ are defined as above. While $S M B_{t}$ is the return on the mimicking size portfolio, $H M L_{t}$ is the return on the mimicking book-to-market portfolio. $\alpha_{i}, \beta_{i}, s_{i}$, and $h_{i}$ are regression coefficients, $e_{i t}$ are the error terms and $N$ is the number of test assets. 
Equation 1 suggests that the CAPM is a restricted three-factor model where the restrictions are $s_{i}=h_{i}=0$.

While there are a number of different ways to test the time-series implications of the CAPM and the threefactor model, this study employs the Generalised Method of Moments (GMM) technique. To utilise the GMM technique, moment conditions are required. For the market model (equation 1) the moment condition are:- first, that the mean regression error term is equal to zero, viz:

$E\left[\varepsilon_{i t}\right]=0 \quad \forall i=1, \ldots, N$

And second, that the regression error is orthogonal to the market return, viz:

$E\left[\varepsilon_{i t} M R P_{t}\right]=0 \quad \forall i=1, \ldots, N$

This gives us $2 N$ sample moment conditions and the system is just-identified and the estimated parameters are equivalent to their ordinary least squares (OLS) counterparts.

Similarly, in the Fama-French three-factor model (equation 2) there are $4 N$ sample moment conditions. The first $2 N$ are identical to the moment conditions in (3) and (4). The additional moment conditions are that the SMB and HML factors are orthogonal to the regression error term:

$$
\begin{aligned}
& E\left[e_{i t} S M B_{m t}\right]=0 \quad \forall i=1, \ldots, N, \\
& E\left[e_{i t} H M L_{m t}\right]=0 \quad \forall i=1, \ldots, N .
\end{aligned}
$$


As the CAPM is a restricted three-factor model with the restriction $s_{i}=h_{i}=0$, this restriction can be tested by forming the following $D$-statistic (Newey $\&$ West, 1987) which has a $\chi^{2}$ distribution;

$T g_{T}\left(\hat{\phi}_{r}\right)^{\prime} S^{-1} g_{T}\left(\hat{\phi}_{r}\right)-T g_{T}\left(\hat{\phi}_{U}\right)^{\prime} S^{-1} g_{T}\left(\hat{\phi}_{U}\right) \sim \chi_{4 N-2 N}^{2}$

where $g_{T}\left(\hat{\phi}_{r}\right)$ and $g_{T}\left(\hat{\phi}_{U}\right)$ are the empirical moment condition vectors for the restricted and unrestricted model respectively, $S^{-1}$ is the optimal weighting matrix and $T$ is the number of observations.

A complete model of excess returns should also result in the pricing errors being equal to zero. This implies that the intercept term in each equation (1) and (2) should equal zero, that is $\alpha_{i}=0$. This implication can be tested using the Gibbons, Ross \& Shanken (1989) (GRS) statistic but this statistic does not take into account heteroskedasticity and autocorrelation in the error terms. To take these into account the $D$-statistic can be used again with the restriction that $\alpha_{i}=0$.

\subsection{Cross-Sectional Framework}

The CAPM and three-factor model can be expressed in the stochastic discount framework (SDF) framework. That is the net return of an asset discounted by the SDF is equal to zero;

$0=E\left[m r_{i}\right]$

where $r_{i}$ is the excess return on the $i$ th asset and $m$ is the SDF. 
The two models (CAPM, and three-factor model) propose two alternate linear stochastic discount factors. The CAPM implies that the stochastic discount factor is a linear function of the market portfolio:

$m=a-b_{M R P} M R P$,

where $r_{m}$ is the market risk premium, and $a$ and $b_{M R P}$ are coefficients in the stochastic discount factor. ${ }^{1}$

The three-factor model implies that the stochastic discount factor is a linear function of the market portfolio, SMB and HML factors:

$m=a-b_{M R P} M R P-b_{S M B} S M B-b_{H M L} H M L$.

where $S M B$, and $H M L$ are the factors mimicking portfolios, capturing the size, and book effects, respectively, and $b_{M R P}, b_{S M B}$, and $b_{H M L}$ are coefficients in the stochastic discount factor.

The parameters in equation (9) can again be estimated using the GMM technique. Since excess returns are used as input to the model, to estimate the parameters in the model we need to normalise the SDF because there is no information on the level of the risk-free (or zero-beta) rate (Cochrane, 2005). If the equation is not normalised then a possible solution would be that both $a$ and $b$ are equal to zero. Consistent with the literature, we normalise the equation by assuming $a$ equals unity (Cochrane, 2005). In the case of the CAPM there are $N$ moment conditions (one for each asset) and one parameter to estimate, i.e. the moment conditions are:

\footnotetext{
${ }^{1}$ The CAPM SDF (equation 10) is written using a negative sign, rather than the more customary positive sign, for convenience. Using a negative sign means that we can expect $b_{M R P}$ to have a positive estimate, which would imply a positive risk premium.
} 
$E\left[r_{i t}\left(1-b_{M R P} M R P_{t}\right)\right]=0 \quad \forall i=1, \ldots, N$,

The three-factor model moment conditions are:

$E\left[r_{i t}\left(1-b_{M R P} M R P_{t}-b_{S M B} S M B_{t}-b_{H M L} H M L_{t}\right)\right]=0 \quad \forall i=1, \ldots, N$.

Since the pricing errors and moment conditions are equivalent, the $J$-statistic can be used to test whether the pricing errors are jointly equal to zero. The $J$-statistic is equal to:

$\mathrm{J}$-stat $=T g_{T}(\hat{\phi})^{\prime} S^{-1} g_{T}(\hat{\phi}) \sim \chi_{N-M}^{2}$

where $g_{T}(\hat{\phi})$ is the empirical moment condition vectors, $S^{-1}$ is the optimal weighting matrix, $T$ is the number of observations, $N$ is the number of moment conditions, and $M$ is the number of parameters to be estimated.

\section{Data \& Portfolio Formation}

As highlighted earlier, the paucity of Australian studies on this topic is crucially related to the availability, or lack thereof, of data. There are two main types of data required for the Fama-French model. First, data are required on accounting information, which is used to calculate book values. Second, prices, dividends, capitalisation changes, and market capitalisation information are required to calculate returns and market values. While the second source of data is available in Australia, there is no comprehensive source of 
financial accounting data available. This has meant that previous studies have covered limited time periods and had limited coverage of stocks.

To substantially improve the quality and coverage of accounting information in Australia, data are handcollected from annual reports for the period 1982 to 2006. Company annual reports were stored by the Australian Stock Exchange (ASX) and its forebears until the mid-1990s when electronic records started to become available. These reports were collected by the now defunct Company Reporting Service (CRS). When this service was closed down, the ASX converted the original hard copy files into either an electronic image files and/or microfiche. These electronic and microfiche files represent the primary source of our annual reports for the period 1981 to 1997 . Note that these documents are the reports that were released to the Exchange. To extend the collection beyond 1997 and supplement the earlier period, annual reports are individually collected from listed companies. Where a copy of the annual report could not be obtained from the company (or its website), broker and university libraries were accessed to complete the collection.

The relevant accounting data is extracted from each annual report and matched against the price data available from the Australian Graduate School of Management (AGSM) Centre for Research in Finance (CRIF) database. Over the time period studied, data are collected from approximately $98 \%$ of all companies that produced an annual report. This is a substantial increase over previous studies in Australia, where accounting information coverage was always less than 50\% of companies that produced an annual report (Gaunt, 2004; Gharghori, Chan \& Faff, 2006, 2007) and in most cases less than 25\% (Durack, Durand \& Maller, 2004; Durand, Limkriangkrai \& Smith, 2006; Halliwell, Heaney \& Sawicki, 1999). 
Following Fama \& French $(1992,1993)$ we define book value as the total value of equity plus deferred tax ${ }^{2}$ minus outside equity interests and the value of preference shares capital. Consistent with previous studies, companies with negative book values ${ }^{3}$ and all property trusts ${ }^{4}$ and investment funds are dropped from the sample. To form book-to-market ratios we match the book values to market capitalisation information from the AGSM-CRIF database. To be consistent with previous literature and to avoid any look-ahead bias, because the release of accounting information is later than the balance date on the annual report, only accounting information that is at least 6 months old is used. For example, book values are calculated for 31 December 1982 so only accounting information released prior to and including 30 June 1982 is used. The final sample comprises 23,098 companies, with the smallest contribution from the year 1982 (522 companies) and the largest from the year 2006 (1291 companies).

Most Australian companies report on a June year-end basis and in our sample, $78.5 \%$ of companies report at 30 June. As we allow a six-month lag from the date on the annual report, the choice of December as the portfolio formation date means the accounting information is as recent as possible for the majority of companies.

Size and book to market portfolios are formed in such a way as to be comparable to the portfolios formed in standard US research. As Brailsford et al. (2011) demonstrate, using the largest 200 Australian firms to determine book-to-market portfolio breakpoints produces portfolios that accord in character with portfolios formed in the original work by Fama and French (1993), so this is the approach adopted here.

\footnotetext{
${ }^{2}$ This is the difference between deferred tax liabilities and deferred tax assets as reported on the balance sheet. This difference is added back as it is unlikely either deferred tax items fits the accounting definition of an asset or liability (see Henderson, Peirson and Herbohn, 2008, p. 320). Such an adjustment is common within the literature (Fama \& French 1992, 1993, 1996, 2006;

Durack, Durand \& Maller, 2004; Durand, Limkriangkrai \& Smith, 2006)

${ }^{3}$ Negative book values make up less than $2.5 \%$ of all collected companies.

${ }^{4}$ These are similar to REITs in the USA.
} 
The 200 largest firms by market capitalization are ranked at the end of each December by their book-tomarket ratio and assigned to one of five book-to-market portfolios, where each portfolio contains an equal number of stocks. The first portfolio (growth) contains $20 \%$ of stocks with the lowest book-to-market ratio. The next $20 \%$ of stocks are assigned to portfolio 2 . The process continues with the last portfolio (value) containing the last $20 \%$ of stocks with the highest book-to-market ratio. These breakpoints are then stored and used to assign all other listed firms into five book-to-market portfolios.

Independently, each firm is ranked by market capitalization again at the end of each December, and assigned to one of five size portfolios. The largest firms that make up $75 \%$ of total market capitalization are assigned to portfolio 1 (large). The next set of firms that make up the next $15 \%$ of total market capitalization are assigned to portfolio 2. Portfolio 3 contains the firms that make up the next $5 \%$ of total market capitalization, while portfolio 4 contains the firms that make up the next $3 \%$ of total market capitalization. Finally the smallest size firms that make up the rest of the total market capitalization is assigned to portfolio 5 (micro). Although somewhat arbitrary, these breakpoints are similar to the total market capitalization assigned to each size portfolios in the US. For example Fama \& French $(1993,2006)$ show that the total market capitalization assigned to their largest size portfolio is $74 \%$, while their smallest size portfolio contains 3\% of total market capitalization (see table 1 and table 2 in Fama \& French 1993; 2006, respectively.). Similarly, Loughran (1997) has $73 \%$ of total market capitalization in their largest size portfolio, while their smallest size portfolio contains $3 \%$ of total market capitalization.

The method used in the US studies is similar to the method described to determine book-to-market portfolios. That is all NYSE listed firms are ranked by market capitalization and five size portfolios are determined, with an equal number of firms in each size portfolios. The breakpoints are then record and used 
to determine the size portfolio NASDAQ and AMEX firms are classified in. As the median market capitalization of NASDAQ and AMEX firms is smaller than the median NYSE listed firms the vast majority of NASDAQ and AMEX firms are classified into the smaller size portfolios. These leads to the largest size portfolio having the smallest number of firms (on average $8 \%$ of the total number of firms Fama $\&$ French 2006 table 2) and the smallest size portfolio having the largest number of firms (on average $60 \%$ of the total number of firms Fama \& French 2006 table 2).

Thus each stock is assigned to one size portfolio and to one book-to-market portfolio. The intersection of these two sorts leads to the creation of twenty-five size-book-to-market portfolios. This process is rolled forward each year and value-weighted returns are calculated. ${ }^{5}$ This results in a series of 300 monthly returns covering the period January 1982 to December 2006 for the twenty-five portfolios.

Table 1 Panel D reports the mean book-to-market ratio of each portfolio. The mean book-to-market ratio is reasonably consistent across the five size quintiles within each book-to-market quintile. For instance, the high growth portfolio across all size sorts has an average book-to-market ratio of 0.28 , with largest size growth portfolio exhibiting a mean book-to-market ratio of 0.30 and the smallest size growth portfolio micro exhibiting a book-to-market ratio of 0.56 . The only slight exception to the general rule of consistent book-to-market ratios is the value classification, where the average book-to-market ratio across all sizes is 2.01, with largest size value portfolio exhibiting a book-to-market ratio of 1.61 while the micro size portfolio has a book-to-market ratio of 2.80 .

\footnotetext{
${ }^{5}$ Equal-weighted portfolio returns have been also calculated. The results of tests that use these portfolio returns are similar and are available from the authors upon request.
} 
Table 1 provides summary information on each of the twenty-five portfolios when portfolios are held for the following twelve months. That is, the returns are value-weighted buy-and-hold strategy. Panel A reports the mean number of companies within each of the twenty-five portfolios. These results demonstrate that growth stocks are generally larger than value firms. For example $18 \%$ of firms in the large size quintile are classified as growth, while only $13 \%$ of firms in the largest size quintile are classified as value. As we move down the size portfolio we find that the vast majority of firms become classified as value, with $46 \%$ of micro firms also classified as value, while only $15 \%$ of firms classified as micro are also classified as growth. That is, value stocks are on average smaller than growth stocks. This finding is consistent with evidence from other markets (Bagella, Becchetti \& Carpentieri, 2000; Elfakhani, Lockwood \& Zaher, 1998; Fama \& French, 1993; 2006).

The result that value stocks are on average smaller than growth stocks, is confirmed by Panel B and C which reports the percentage of total market capitalization in each portfolio and the mean market capitalisation of the portfolios, respectively. Panel B indicates that the growth portfolio in the large size quintile contains $16.4 \%$ of total market capitalization, on average. In contrast the value portfolio in the large size quintile only contains $7.7 \%$ of total market capitalization. Panel $\mathrm{C}$ indicates that the mean market capitalisation of the growth portfolio in the large quintile is $\$ 5128.67$ million, while the value portfolio has a lower mean market capitalisation of $\$ 4506.82$ million.

Table 1 Panel D reports the mean book-to-market ratio of each portfolio. The mean book-to-market ratio is reasonably consistent across the five size quintiles within each book-to-market quintile. For instance, the high growth portfolio across all size sorts has an average book-to-market ratio of 0.28 , with largest size growth portfolio exhibiting a mean book-to-market ratio of 0.30 and the smallest size growth portfolio micro exhibiting a book-to-market ratio of 0.56 . The only slight exception to the general rule of consistent 
book-to-market ratios is the value classification, where the average book-to-market ratio across all sizes is 2.01, with largest size value portfolio exhibiting a book-to-market ratio of 1.61 while the micro size portfolio has a book-to-market ratio of 2.80 . 


\section{Table 1}

\section{Characteristics of portfolios sorted on size and book-to-market}

This table presents the mean number of companies, market capitalisation and book-to-market ratios of the twenty-five size-book-to-market portfolios. The twenty-five size-book-to-market portfolios are formed by first ranking the 200 largest firms by their book-to-market ratio and assigned to one of five book-to-market portfolios, where each portfolio contains an equal number of stocks each December. These breakpoints are then used to assign all other listed firms into five book-to-market portfolios. Independently, all stocks are ranked by their market capitalisation and assigned to one of five size portfolios with largest firms that make up 75\% of total market capitalization assigned to portfolio 1 (large). The next $n$ number of firms that make up the next $15 \%$ of total market capitalization assigned to portfolio 2 . Portfolio 3 contains the next $5 \%$ of total market capitalization, portfolio 4 contains the next $3 \%$ of total market capitalization with the remaining firms classified in portfolio 5 (micro). The intersection of the five book-to-market portfolios and the five size portfolios leads to the creation of our twenty-five portfolios.

\section{Panel A: Number of Companies}

\begin{tabular}{ccccccc}
\hline & Growth & 2 & 3 & 4 & Value & Total \\
\hline Large & 11 & 15 & 14 & 12 & 7 & 59 \\
2 & 20 & 16 & 17 & 19 & 18 & 91 \\
3 & 18 & 17 & 17 & 18 & 28 & 97 \\
4 & 27 & 21 & 24 & 29 & 52 & 153 \\
Micro & 88 & 70 & 74 & 97 & 281 & 610 \\
Total & 164 & 138 & 147 & 176 & 386 &
\end{tabular}

Panel B: Percentage of Total Market Capitalisation

\begin{tabular}{ccccccc}
\hline & Growth & 2 & 3 & 4 & Value & Total \\
\hline Large & 16.35 & 21.28 & 17.11 & 12.72 & 7.71 & 75 \\
2 & 3.27 & 2.89 & 2.92 & 3.09 & 2.70 & 15 \\
3 & 0.92 & 0.84 & 0.89 & 0.94 & 1.39 & 5 \\
4 & 0.53 & 0.41 & 0.47 & 0.59 & 1.00 & 3 \\
Micro & 0.31 & 0.27 & 0.27 & 0.35 & 0.79 & 2 \\
Total & 21 & 26 & 22 & 18 & 14 &
\end{tabular}

Panel C: Mean Market Capitalisation (\$ millions)

\begin{tabular}{crrrrr}
\hline & Growth & \multicolumn{1}{c}{2} & \multicolumn{1}{c}{3} & \multicolumn{1}{c}{4} & \multicolumn{1}{c}{ Value } \\
\hline Large & 5128.7 & 6287.9 & 5340.7 & 3870.8 & 4506.8 \\
2 & 694.1 & 699.3 & 659.2 & 652.6 & 618.9 \\
3 & 207.5 & 211.1 & 211.6 & 215.8 & 205.9 \\
4 & 74.2 & 75.3 & 74.6 & 73.2 & 74.9 \\
Micro & 12.2 & 13.5 & 12.8 & 12.2 & 9.7
\end{tabular}

Panel D: Mean Book to Market Ratios

\begin{tabular}{cccccc}
\hline & Growth & 2 & 3 & 4 & Value \\
\hline Large & 0.30 & 0.53 & 0.72 & 0.96 & 1.61 \\
2 & 0.28 & 0.53 & 0.73 & 0.97 & 1.78 \\
3 & 0.28 & 0.53 & 0.72 & 0.97 & 2.00 \\
4 & 0.27 & 0.54 & 0.73 & 0.98 & 1.87 \\
Micro & 0.25 & 0.53 & 0.73 & 0.97 & 2.80 \\
\hline
\end{tabular}




\section{Portfolio Analysis}

\subsection{Portfolio Returns}

We now turn to the return performance of the 25 portfolios sorted on size and book-to-market. We define five new portfolios as "value minus growth" (VMG) within each size quintile. The VMG portfolios are formed from the difference between the return of the value portfolio less the return on the growth portfolio within each size quintile and hence represent the size-adjusted value premium. Table 2 Panel A reports the average monthly returns of the portfolios.

These results from Table 2 indicate that the growth portfolios within each size quintile earn the lowest return. As we move towards the value portfolios in each size quintile, returns steadily increase with the extreme value portfolios earning the highest return. The $t$-statistic in Panel A indicates that the VMG portfolio has a mean return significantly different from zero across all size quintiles.

Focusing on the VMG portfolio, these results clearly demonstrate a premium for value firms across each size quintile with the average monthly return across the five VMG portfolios being $0.93 \%$. This result indicates that size has effectively been neutralized across the portfolios within each size quintile. 


\section{Table 2}

\section{Return Characteristics of Size and Book-to-market sorted portfolios}

Presented are the mean monthly returns, standard deviation of monthly returns, mean monthly excess returns and $t$-statistic of each of the twenty-five size-book-to-market portfolios and five value minus growth (VMG) portfolios during the period 1982 to 2006 when portfolios are rebalanced annually. The VMG portfolios are formed as the difference between the return of the value portfolio less the return on the growth portfolio within each size quintile.

** and $*$ denote significance at the $1 \%$ and $5 \%$ levels respectively.

\begin{tabular}{crrrrrrrr}
\multicolumn{7}{c}{ Panel A: Mean Monthly Returns (\%) } \\
& Growth & 2 & 3 & 4 & Value & VMG & $t$-stat \\
\hline Large & 0.66 & 1.08 & 1.27 & 1.33 & 1.64 & 0.98 & $2.82^{* *}$ \\
2 & 0.73 & 1.04 & 1.27 & 1.16 & 1.42 & 0.70 & $2.65^{* *}$ \\
3 & 0.13 & 1.11 & 1.27 & 0.83 & 1.51 & 1.38 & $4.34^{* *}$ \\
4 & 0.38 & 0.64 & 0.93 & 1.08 & 1.23 & 0.85 & $2.70^{* *}$ \\
Micro & 0.84 & 1.04 & 1.23 & 1.40 & 1.56 & 0.72 & $2.38^{*}$ \\
\hline
\end{tabular}

Panel B: Standard Deviation (\%)

\begin{tabular}{ccccccc} 
& Growth & 2 & 3 & 4 & Value & VMG \\
\hline Large & 5.60 & 5.07 & 5.16 & 4.82 & 6.47 & 6.03 \\
2 & 6.37 & 4.87 & 4.87 & 4.44 & 4.29 & 4.56 \\
3 & 6.58 & 5.36 & 5.17 & 4.36 & 4.29 & 5.52 \\
4 & 7.46 & 5.10 & 5.30 & 4.17 & 4.45 & 5.42 \\
Micro & 8.74 & 6.96 & 5.82 & 5.68 & 5.24 & 5.24 \\
\hline
\end{tabular}

\begin{tabular}{crrrrr}
\multicolumn{7}{c}{ Panel C: Mean Excess Monthly Returns (\%) } \\
& Growth & \multicolumn{1}{c}{2} & 3 & 4 & Value \\
\hline Large & -0.03 & 0.39 & 0.59 & 0.64 & 0.95 \\
2 & 0.04 & 0.35 & 0.58 & 0.47 & 0.73 \\
3 & -0.56 & 0.42 & 0.58 & 0.14 & 0.82 \\
4 & -0.31 & -0.05 & 0.24 & 0.39 & 0.54 \\
Micro & 0.15 & 0.35 & 0.54 & 0.71 & 0.87 \\
\hline
\end{tabular}

Panel D: $t$-statistics for mean excess monthly returns

\begin{tabular}{crrrrr} 
& Growth & \multicolumn{1}{c}{2} & \multicolumn{1}{c}{3} & \multicolumn{1}{c}{4} & \multicolumn{1}{c}{ Value } \\
\hline Large & -0.09 & 1.35 & 1.96 & $2.29^{*}$ & $2.54^{*}$ \\
2 & 0.10 & 1.24 & $2.08^{*}$ & 1.85 & $2.94^{* *}$ \\
3 & -1.48 & 1.35 & 1.93 & 0.56 & $3.28^{* *}$ \\
4 & -0.71 & -0.17 & 0.79 & 1.62 & $2.08^{*}$ \\
Micro & 0.30 & 0.88 & 1.60 & $2.16^{*}$ & $2.88^{* *}$ \\
\hline
\end{tabular}


The highest value premium is observed in size quintile three with the lowest premium observed in the second size portfolio. This premium is larger than that indicated by evidence from North America, where the value premium is usually around $0.5 \%$ per month in the USA and Canada when portfolio and returns are calculated in a similar way (Elfakhani, Lockwood \& Zaher, 1998; Fama \& French, 1993, 1996, 2006). In contrast, the Australian value premium is similar to a selection of Asian markets where the premium is around $0.6 \%$ in excess of the risk-free rate when stocks are divided into three size and three book-to-market portfolios (Chui \& Wei, 1998). ${ }^{6}$ Considering the relative sizes of the various markets, there is a loose argument that the size of the value premium may be (inversely) connected to market size and liquidity.

Table 2 Panel B, reports the standard deviation of returns on each of the portfolios. These results indicate that the five book-to-market portfolios have similar volatility in returns within the largest size quintile. However, as size declines the standard deviations change disproportionately, with the growth portfolios having a higher volatility compared to the value portfolios. There is strong evidence of a general pattern occurring with the smaller size portfolios having higher volatility in returns. Among the various arguments for this finding is the observation that small stocks typically have a lower price per share. This implies that small stocks are more likely to display higher volatility because a small change in price leads to a larger percentage change. These results would also be consistent with relatively illiquid stocks characterised by large bid-ask spreads comprising the small portfolios.

Table 2 Panel C and D reports mean monthly excess returns (portfolio returns are in excess of the 13-week treasury yield) of the twenty-five size-book to market portfolios and the $t$-statistic which tests whether these mean monthly excess returns are significantly different from zero. These results confirm the results in Table

\footnotetext{
${ }^{6}$ The Asian emerging markets are Hong Kong with a premium of $1.1 \%$ per month, Korea with a premium of $1.0 \%$, Malaysia with a premium of $0.5 \%$, Taiwan with a premium of $-0.5 \%$ and Thailand with a premium of $0.8 \%$.
} 
2 Panel A that the value portfolios consistently outperform the growth portfolios across all size quintiles. These results demonstrate that the value portfolios have mean monthly excess returns significantly different from zero, while the growth portfolio have insignificantly different returns.

Using the two independent sorts there is also evidence that average returns first decline as size declines, with stocks within size quintile 4 earning the lowest mean monthly return of $0.85 \%{ }^{7}$ The mean monthly return then increase as we move towards the smallest size quintile, which has the highest mean monthly return of $1.22 \%$. Such a pattern is consistent with the well-known size effect even when book-to-market is controlled. A similar u-shaped pattern has been documented in previous Australian studies (Gharghori, Chan \& Faff, 2006) and has been documented elsewhere in Canada (Elfakhani, Lockwood \& Zaher, 1998) and Taiwan (Chui and Wei, 1998).

In summary, the results indicate that there is a value premium in Australia once we control for size effects, and that the value premium is prevalent in all size quintiles and relatively consistent. Hence, it is possible that the value anomaly could be exploited in Australia.

\subsection{Mimicking Portfolio Construction}

Given the inherent empirical nature of the study, there is no strong theory to guide the method of formation for the mimicking portfolios. In the absence of any strong alternate argument, we construct the factors SMB and $\mathrm{HML}^{8}$ following the methodology and spirit of Fama \& French (1993). That is, all firms on the ASX are ranked by market capitalisation (largest to smallest) and the first $n$ number of firms that make up $90 \%$ of total market capitalization are assigned to the big portfolio. All other firms are assigned to the small

\footnotetext{
${ }^{7}$ This is the mean of the mean monthly returns of the five portfolios within size quintile 4 i.e. $(0.38+0.64+0.93+1.08+1.23) / 5$.

${ }^{8}$ It is anticipated that these factors will in the future be made available to researchers via a web page. For more information contact the authors directly.
} 
portfolio. Independently the top 200 firms by market capitalization are ranked by their book-to-market ratios. The first $30 \%$ of firms with the lowest book-to-market ratios are assigned to the low portfolio. The next $40 \%$ of firms based on book-to-market ratio are assigned to the neutral portfolio and finally the $30 \%$ of firms with the highest book-to-market are assigned to the high portfolio. These book-to-market breakpoints are recorded and used to assign all other firms outside the top 200 into the three book-to-market portfolios. This leads to all stocks being assigned to one of two size portfolios and one of three book-to-market portfolios giving a total of six portfolios. These portfolios are subsequently held for twelve months and value-weighted returns are calculated. After each twelve months the process is repeated and portfolios are re-formed. The SMB factor is then calculated as the difference between the average value-weighted return across the three small portfolios (small-low, small-neutral and small-high) and the average value-weighted return across the three big portfolios (big-low, big-neutral and big-high). Similarly the HML factor is calculated as the difference between the average value-weighted return across the two high book-to-market portfolios (big-high and small-high) and the average value-weighted return across the two low book-tomarket portfolios (big-low and small-low).

The classification of the big portfolio, that is firms that make up $90 \%$ of total market capitalization are big, is similar to the studies in the US that use the SMB and HML factors and consistent with Fama \& French 2008 where the big portfolio contains, on average, 90\% of total market capitalization over the period 19632005 (see Table 1 p1657).

Table 3 Panel A reports the average monthly returns of the two factors in Australia. Also reported are the average monthly value-weighted return to the market risk premium in Australia (MRP) which is calculated 
as the monthly market return less the 13-week treasury note yield with both extracted from the AGSM-

CRIF price relative file. Table 3 Panel B reports the correlation coefficients between each of the factors.

\section{Table 3}

\section{Descriptive statistics and correlations between factors}

Panel A reports basic descriptive statistics for monthly returns on the Australian factors SMB and HML and the value-weighted market risk premium (MRP) for the period 1982 to 2006 . The $t$-statistic and $z$-value tests whether the mean and median are different from zero. The correlation coefficients between each factor is report in Panel B. The market risk premium is extracted from the AGSM-CIRF price relative file. $* *$ and $*$ denote significance at the $1 \%$ and $5 \%$ levels.

\begin{tabular}{lccc}
\hline & SMB & HML & MRP \\
\hline \multicolumn{3}{c}{ Panel } & A: Descriptive Statistics \\
Mean & -0.22 & 0.76 & 0.51 \\
Median & -0.18 & 0.69 & 0.98 \\
Minimum & -9.19 & -12.69 & -40.37 \\
Maximum & 7.21 & 8.95 & 14.16 \\
Std. Dev. & 2.96 & 2.67 & 4.59 \\
t-stat. & -1.31 & $4.94^{* *}$ & 1.92 \\
z-value & -1.19 & $-4.88^{* *}$ & $-3.10^{* *}$ \\
\multicolumn{4}{c}{} \\
SMB & Panel B: Correlations \\
HML & 1 & \\
MRP & -0.31 & 1 & \\
\hline
\end{tabular}

Starting with the SMB factor the mean (median) monthly return is $-0.22 \%(-0.18 \%)$ per month which are not significantly different from zero. This negative, though insignificant difference, between the small portfolio and big portfolio is consistent with recent evidence overseas that indicate that the size premium has substantial declined since its initial reporting in the early 1980's (Dimson \& Marsh, 1999; Horowitz, et al., 2000a, b). Although previous research on the size premium in Australia (Beedles, Dodd \& Officer, 1988; Durand, Juricev, \& Smith, 2007) suggest a substantial size premium, these studies demonstrated that the small premium only resides in companies whose average market capitalisations are less than $\$ 3$ million. The companies make up less than $0.5 \%$ of total market capitalization in Australia. As the small portfolio is made up of companies that make up the last $10 \%$ of total market capitalization and is value-weighted the 
importance of the extremely small companies are substantially reduced. ${ }^{9}$ These results also indicate moderate variation in the SMB premium with the maximum return during the 25 year period being $7.21 \%$ per month and the lowest being $-9.19 \%$, with a standard deviation of $2.96 \%$.

The SMB average is substantially smaller than Durack, Durand, \& Maller (2004), Durand, Juricev, \& Smith (2007) and Gharghori, Chan, \& Faff (2006, 2007). Gharghori, Chan, \& Faff (2006) during the period 1990 to 2003 found a premium of $3.69 \%$, while in the period 1996 to 2004 this had reduced substantially to 1.43\% per month (Gharghori, Chan, \& Faff, 2007). Halliwell, Heaney \& Sawicki (1999) and Gharghori, Chan, \& Faff $(2006,2007)$ define big as those companies above the median market capitalization and small as all companies below the median market capitalization, while Durack, Durand, \& Maller (2004), Durand, Juricev, \& Smith (2007) define big as the first $30 \%$ of total number of companies, while small is the final $30 \%$ of total number of companies. These definitions mean that the firms whose market capitalization is less than $\$ 3$ million have a greater weight in the calculation of SMB compared to our methodology leading to the higher mean returns.

The results in Table 3 Panel A indicate that the HML factor earns a mean (median) monthly return of $0.76 \%$ $(0.69 \%)$. The mean (median) are both significantly different from zero with a $t$-statistic ( $z$-value) of 4.94 (4.88). The mean (median) results are of a similar magnitude to previous studies on the HML factor in Australia. Halliwell, Heaney \& Sawicki (1999) report a premium of approximately $1.2 \%$ per month during 1981 to 1991 , while Gharghori, Chan, \& Faff (2006) report a premium of $1.18 \%$ per month during 1990 to 2003, which reduces to $0.87 \%$ in the period 1996 to 2004 .

\footnotetext{
${ }^{9}$ It should be noted that the mean (median) monthly return of the USA SMB factor is $0.09 \%(-0.13 \%)$ per month during the time period 1982 to 2006, which is also insignificantly different from zero.
} 
Turning to the correlation coefficients, the results in Table 3 Panel B indicate that the HML and SMB factors have a moderate negative correlation between them of -0.31 . The factor formation technique attempts to isolate the size, and book-to-market effects, and the moderate correlation coefficient suggests this has been successful. The moderate correlation coefficients suggest multicollinearity should not affect the regression results. The results also indicate low correlation between MRP and the factors (SMB-MRP is -0.21, and HML-MRP is -0.24). This low correlation suggests that the factors are gaining exposure to variations in the stock market not captured by the market risk premium.

In Figure $1^{10}$ we have plotted the efficient frontier constructed using all 28 assets: the 25 size and book-tomarket sorted portfolios and the 3 Fama-French factors. Portfolio theory asserts that assets whose returns are imperfectly correlated will, when combined, produce portfolios which benefit from risk reduction. For negatively correlated assets this risk reduction effect can be significant. Table 3 reports negative correlations for the 3 factors and, in unreported results, there is some evidence of negative correlation between the factors and the 25 dual-sort portfolios. Figure 1 clearly shows that all 28 assets plot inside the efficient frontier, and removes any concerns that the SMB and HML factors may be ex post efficient frontier portfolios.

\footnotetext{
${ }^{10}$ We thank an anonymous referee for suggesting this.
} 
Figure 1

Mean-Variance Frontier for $\mathbf{2 8}$ assets ( 25 dual sort portfolios, $\mathrm{mkt}, \mathrm{hml}, \mathrm{smb}$ )

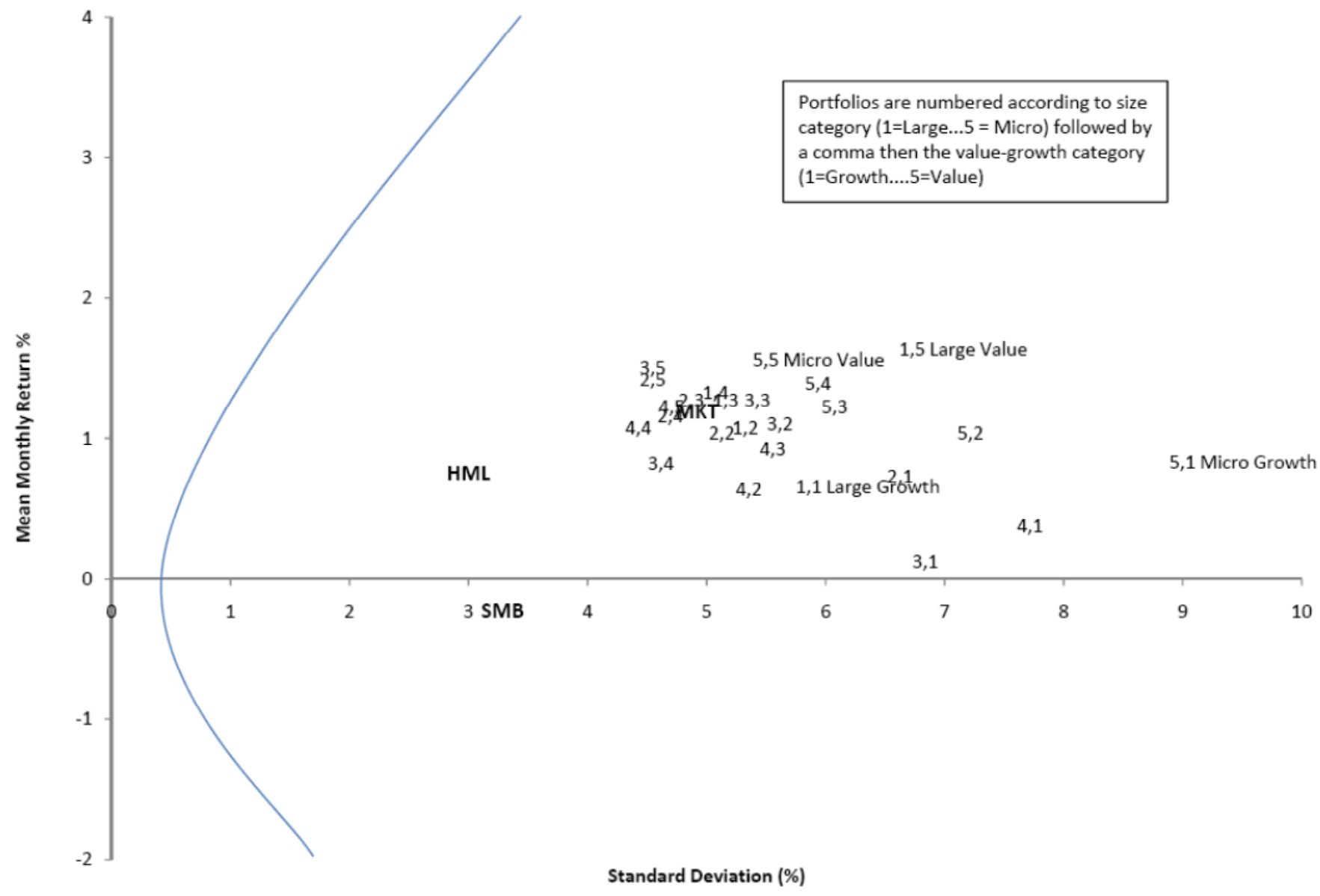




\section{Table 4}

\section{Regression results from the CAPM}

This table presents the results from regressing the 300 excess monthly returns of each of the 25 size-book-to-market portfolios on excess market returns. The 25 size-book-to-market portfolios are formed by using independent sorts based on market capitalisation and book-to-market ratios during the period 1982 to 2006. The following time-series regression is estimated:

$r_{i t}=\alpha_{i}+\beta_{i} M R P_{t}+\varepsilon_{i t} \quad i=1, \ldots, N$.

Where $r_{i t}$ is the return on portfolio $i$ in month $t$ less the 13-week treasury note yield and $M R P_{t}$ is the value-weighted market monthly return less the 13-week treasury note yield. Both the market return and the 13-week treasury note yields are extracted from the CRIF price relative file. The system is estimated using the GMM technique. The $t$-statistic for the regression coefficients uses HAC standard errors. The adjusted $R^{2}$ are calculated for each equation in the system. The Gibbons, Ross and Shanken (1989)\} (GRS) test statistic, and the Newey and West (1987) $D$-statistic test whether $\alpha_{i}=0$, are also reported.

** and * denote significance at the $1 \%$ and $5 \%$ levels respectively.

\begin{tabular}{|c|c|c|c|c|c|c|c|c|c|c|c|}
\hline \multicolumn{6}{|c|}{ Coefficient } & \multicolumn{6}{|c|}{$t$-statistic } \\
\hline$\alpha_{i}$ & Growth & 2 & 3 & 4 & Value & & Growth & 2 & 3 & 4 & Value \\
\hline Large & -0.51 & -0.12 & 0.07 & 0.20 & 0.41 & Large & $-2.15^{\star}$ & -0.89 & 0.51 & 1.03 & 1.36 \\
\hline 2 & -0.53 & -0.10 & 0.14 & 0.07 & 0.34 & 2 & $-1.98^{\star}$ & -0.56 & 0.67 & 0.38 & 1.92 \\
\hline 3 & -1.03 & 0.00 & 0.15 & -0.21 & 0.45 & 3 & $-2.74^{\star *}$ & -0.01 & 0.73 & -0.95 & $2.14^{*}$ \\
\hline 4 & -0.88 & -0.41 & -0.14 & 0.08 & 0.16 & 4 & $-2.31^{*}$ & -1.44 & -0.51 & 0.35 & 0.71 \\
\hline Micro & -0.43 & -0.12 & 0.17 & 0.33 & 0.49 & Micro & -0.87 & -0.30 & 0.48 & 0.97 & 1.61 \\
\hline$\beta_{i}$ & Growth & 2 & 3 & 4 & Value & & Growth & 2 & 3 & 4 & Value \\
\hline Large & 0.93 & 1.01 & 1.02 & 0.86 & 1.06 & Large & $14.66^{* *}$ & $19.26^{\star *}$ & $30.87^{* *}$ & $19.71^{* *}$ & $19.85^{\star *}$ \\
\hline 2 & 1.12 & 0.88 & 0.87 & 0.80 & 0.77 & 2 & $21.27^{* *}$ & $19.84^{\star *}$ & $18.47^{* \star}$ & $21.25^{\star \star}$ & $21.97^{\star *}$ \\
\hline 3 & 0.92 & 0.83 & 0.83 & 0.69 & 0.73 & 3 & $7.60^{* *}$ & $16.94^{\star *}$ & $13.60^{* *}$ & $19.14^{* *}$ & $11.86^{\star *}$ \\
\hline 4 & 1.12 & 0.71 & 0.75 & 0.62 & 0.75 & 4 & $14.09^{* *}$ & $12.18^{* \star}$ & $10.41^{* *}$ & $12.46^{\star *}$ & $17.62^{\star *}$ \\
\hline Micro & 1.14 & 0.94 & 0.72 & 0.75 & 0.76 & Micro & 8.39 ** & $12.22^{\star \star}$ & $10.82^{\star *}$ & $10.74^{* *}$ & $14.18^{\star \star}$ \\
\hline
\end{tabular}

\begin{tabular}{|c|c|c|c|c|c|}
\hline \multicolumn{6}{|c|}{ Adj $R^{2}$} \\
\hline \multicolumn{2}{|c|}{ Growth } & 2 & 3 & 4 & Value \\
\hline Large & 0.59 & 0.83 & 0.81 & 0.67 & 0.57 \\
\hline 2 & 0.65 & 0.68 & 0.68 & 0.68 & 0.67 \\
\hline 3 & 0.40 & 0.50 & 0.55 & 0.52 & 0.59 \\
\hline 4 & 0.47 & 0.41 & 0.42 & 0.46 & 0.58 \\
\hline Micro & 0.36 & 0.38 & 0.32 & 0.37 & 0.44 \\
\hline \multicolumn{2}{|c|}{ GRS } & \multicolumn{4}{|l|}{$2.64^{* *}$} \\
\hline \multicolumn{2}{|c|}{$D$-test, $\alpha_{i}=0$} & $73.03^{* *}$ & & & \\
\hline
\end{tabular}




\section{Regression Results}

\subsection{Time-Series Regressions}

Results from estimating Equation (1) to explain the 25 portfolio returns are reported in Table 4. Starting with the beta estimates, the results indicate that the growth portfolio within each size quintile always has a higher beta estimate then the corresponding value portfolio, with the exception of the large size quintile. For example, the 2-size/1-BM portfolio has a beta estimate of 1.12 while the 2-size/5-BM portfolio has a beta estimate of 0.77. Given our findings above that value portfolios have higher mean returns, this result that value portfolios have lower beta risk compared to growth portfolios suggests that the CAPM does not explain the differences in returns. That is, if the only source of risk is market risk - as proposed by the CAPM - then the higher mean returns earned by the value portfolios should lead to a higher loading on the market risk premium, i.e. higher estimated betas. This finding was significant in leading to the development of the original three-factor model (Fama \& French, 1992, 1993).

We now turn to the beta estimates across the size portfolios. Earlier we found little evidence of the size premium by showing that the portfolios within the micro quintile had similar mean monthly return compared to portfolios within the large size quintile. If the CAPM correctly captures this insignificant difference in returns, then the portfolios in the micro quintile should have similar beta estimates than portfolios in the large size quintile. In fact the results in Table 4 indicate that portfolios within the large quintile generally have higher beta estimates. The exception is portfolios also classified as growth, which have higher beta estimates for the micro size quintile. Even though the beta estimates are not consistent with the CAPM explaining the value effect it should be noted that all beta estimates are significant at the one percent level suggesting that the market risk premium is still important in explaining returns. 
The results thus far suggest that beta risk does not explain the differences in returns between growth and value portfolios in Australia. To confirm this finding the estimates on the intercept terms are now examined. If the CAPM fully explained the returns on the 25 portfolios, then the intercepts should not be significantly different from zero (Black, Jensen \& Scholes, 1972). Results indicate that a number of the intercept terms are statistically different from zero. In particular, growth portfolios within the four largest size quintiles exhibit a negative alpha, indicating that these portfolios do not earn a return consistent with their beta risk. There is also evidence that alphas increase as we move from the growth classification to the value classification, although nearly all other portfolios have insignificant alphas, with the exception of portfolio 3-size/5-BM. To formally test whether all the intercepts are jointly equal to zero the $G R S$ and $D$ statistics are calculated. These results indicate that both statistics are statistically significant, indicating we should reject the null that all intercepts are jointly equal to zero.

Although the intercept terms for the majority of value portfolios are insignificant it is interesting that they generally have the highest estimate within their size quintile. In particular we note that the large-value portfolio has an intercept term of 0.41 , suggesting a monthly unexplained return of $0.641 \%$ per month. There is also evidence of some non-linearities in the size effect with portfolios within size quintile 4 generally exhibiting the lowest intercepts when compared to their equivalent book-to-market portfolios. These results are consistent with the earlier results reported in Table 2 .

Table 5 presents the results from estimating Equation (2) on the 25 value-weighted portfolio returns. Results indicate that beta estimates are significant for all portfolios, again indicating that exposure to the market risk premium is extremely important in explaining variation in returns. 
Turning to the estimate of $s$, which captures the amount each portfolio loads onto the SMB factor. As expected, the loading on the SMB steadily increases as we move from the largest quintile to the micro quintile. In fact, the portfolios within the largest quintile have a slight negative or insignificant loading on $\mathrm{SMB}$, while portfolios within the micro quintile demonstrate a large positive and significant loading on SMB. This monotonic relationship between size and the SMB factor is consistent with previous studies (Durand, Limkriangkrai \& Smith, 2006; Fama \& French, 1993, 1996, 2006; Gaunt, 2004; Gharghori, Chan \& Faff, 2007; Halliwell, Heaney \& Sawicki, 1999). As portfolios within the micro portfolios have low market capitalisation by definition, they should co-vary positively with the SMB factor.

There is also evidence of a decreased loading on SMB as we move from growth to value portfolios, except for portfolios within the largest quintile. With the exception of three of the large portfolios all $s$ coefficients are statistically different from zero. These results indicate that SMB is indeed an important factor in the Australian equity market.

The influence of the HML factor on portfolio returns also demonstrates a regular pattern related to changes in book-to-market ratios. First, portfolios classified in the growth quintile have negative loadings on the HML factor, with all estimates being significantly different from zero except the micro-growth portfolio. Second, the loading increases as average book-to-market ratios increase, leading to a strong positive and significant factor loading for the value portfolios. This result is the strongest evidence documented in Australia that HML possesses explanatory power. These results are consistent with international studies on the three-factor model (Bagella, Becchetti \& Carpentieri, 2000; Davis, Fama \& French, 2000; Fama \& French, 1993, 1996, 1998). 


\section{Table 5}

\section{Regression results from the three-factor model}

This table presents the results from regressing the 300 excess monthly returns of each of the 25 size-book-to-market portfolios on excess market returns. The 25 size-book-to-market portfolios are formed by using independent sorts based on market capitalisation and book-to-market ratios during the period 1982 to 2006. The following time-series regression is estimated:

$r_{i t}=\alpha_{i}+\beta_{i} M R P_{t}+s_{i} S M B_{i t}+h_{i} H M L_{i t}+e_{i t} \quad i=1, \ldots, N$.

Where $r_{i t}$ is the return on portfolio $i$ in month $t$ less the 13-week treasury note yield, $M R P_{t}$ is the value-weighted market monthly return less the 13-week treasury note yield. $S M B_{t}$ is the return on the mimicking size portfolio and $H M L_{t}$ is the return on the mimicking book-to-market portfolio. Both mimicking portfolios are formed using two size and three book-to-market portfolio splits. The system is estimated using the GMM technique. The $t$-statistic for the regression coefficients uses HAC standard errors. The adjusted $R^{2}$ are calculated for each equation in the system. The GRS test statistic, and two $D$-statistics, which test various restrictions, are also reported.

$* *$ and $*$ denote significance at the $1 \%$ and $5 \%$ levels respectively.

\begin{tabular}{|c|c|c|c|c|c|c|c|c|c|c|c|}
\hline \multicolumn{6}{|c|}{ Coefficient } & \multicolumn{6}{|c|}{$t$-statistic } \\
\hline$\alpha_{i}$ & Growth & 2 & 3 & 4 & Value & & Growth & 2 & 3 & 4 & Value \\
\hline Large & 0.13 & 0.08 & 0.00 & -0.07 & -0.21 & Large & 0.50 & 0.50 & -0.03 & -0.33 & -0.65 \\
\hline 2 & -0.22 & -0.04 & 0.09 & -0.11 & 0.10 & 2 & -1.04 & -0.21 & 0.41 & -0.61 & 0.55 \\
\hline 3 & -0.30 & 0.03 & 0.24 & -0.37 & 0.18 & 3 & -0.95 & 0.12 & 1.23 & -1.86 & 1.11 \\
\hline 4 & -0.34 & -0.26 & -0.12 & -0.02 & 0.08 & 4 & -1.17 & -1.20 & -0.43 & -0.12 & 0.47 \\
\hline Micro & 0.11 & 0.29 & 0.35 & 0.38 & 0.45 & Micro & 0.27 & 1.14 & 1.48 & 1.66 & $2.42^{*}$ \\
\hline$\beta_{i}$ & Growth & 2 & 3 & 4 & Value & & Growth & 2 & 3 & 4 & Value \\
\hline Large & 0.74 & 0.95 & 1.01 & 0.88 & 1.14 & Large & $13.41^{* *}$ & $18.43^{\star \star}$ & $26.83^{\star *}$ & $20.17^{\star *}$ & $16.09^{\star * *}$ \\
\hline 2 & 1.16 & 0.91 & 0.92 & 0.87 & 0.86 & 2 & $24.94^{\star *}$ & $19.24^{\star *}$ & $15.90^{* *}$ & $21.42^{\star *}$ & $19.66^{\star *}$ \\
\hline 3 & 0.94 & 0.96 & 0.94 & 0.82 & 0.87 & 3 & $9.95^{\star *}$ & $19.99^{* *}$ & $15.62^{* *}$ & $18.67^{* *}$ & $16.23^{\star *}$ \\
\hline 4 & 1.20 & 0.82 & 0.88 & 0.75 & 0.88 & 4 & $22.47^{* *}$ & $14.10^{\star *}$ & $11.50^{* \star}$ & $13.80^{* *}$ & $20.04^{* *}$ \\
\hline Micro & 1.32 & 1.08 & 0.89 & 0.95 & 0.95 & Micro & $10.29^{* *}$ & $17.09^{* *}$ & $14.14^{\star *}$ & $15.56^{* *}$ & $21.85^{\star *}$ \\
\hline
\end{tabular}




\begin{tabular}{|c|c|c|c|c|c|c|c|c|c|c|c|}
\hline$s_{i}$ & Growth & 2 & 3 & 4 & Value & & Growth & 2 & 3 & 4 & Value \\
\hline Large & -0.57 & -0.13 & -0.10 & -0.11 & -0.14 & Large & $-4.43^{\star *}$ & $-2.06^{*}$ & -1.50 & -1.57 & -1.46 \\
\hline 2 & 0.55 & 0.29 & 0.22 & 0.22 & 0.32 & 2 & $6.78^{\star *}$ & $3.98^{* *}$ & $3.07^{* *}$ & $2.87^{* *}$ & $4.37^{* *}$ \\
\hline 3 & 0.91 & 0.80 & 0.71 & 0.65 & 0.59 & 3 & $8.62^{* *}$ & $9.97^{* \star}$ & $7.57^{* *}$ & $7.39^{* *}$ & $7.47^{\text {** }}$ \\
\hline 4 & 1.05 & 0.82 & 0.79 & 0.69 & 0.74 & 4 & $10.61^{* *}$ & $9.56^{\star *}$ & $7.05^{\star *}$ & $8.16^{\star *}$ & $7.82^{* *}$ \\
\hline Micro & 1.65 & 1.31 & 1.19 & 1.23 & 1.14 & Micro & $10.77^{* *}$ & $12.69^{* *}$ & $10.97^{* *}$ & $10.64^{* *}$ & $11.21^{* *}$ \\
\hline$h_{i}$ & Growth & 2 & 3 & 4 & Value & & Growth & 2 & 3 & 4 & Value \\
\hline Large & -0.87 & -0.26 & 0.07 & 0.30 & 0.71 & Large & $-5.67^{* *}$ & $-3.97^{* *}$ & 1.03 & $3.34^{* *}$ & $6.07^{* *}$ \\
\hline 2 & -0.28 & -0.02 & 0.10 & 0.25 & 0.35 & 2 & $-2.91^{\star *}$ & -0.20 & 1.10 & $3.48^{* *}$ & $4.04^{* *}$ \\
\hline 3 & -0.71 & 0.11 & 0.02 & 0.31 & 0.43 & 3 & $-5.70^{\star *}$ & 1.07 & 0.26 & $3.24^{* *}$ & $5.30^{* *}$ \\
\hline 4 & -0.45 & -0.03 & 0.11 & 0.25 & 0.23 & 4 & $-3.84^{\star \star}$ & -0.35 & 1.35 & $2.60^{\star \star}$ & $2.20^{*}$ \\
\hline Micro & -0.34 & -0.26 & 0.00 & 0.16 & 0.25 & Micro & -1.82 & $-2.58^{*}$ & 0.00 & 1.31 & $2.48^{*}$ \\
\hline \multicolumn{12}{|c|}{ Adj $R^{2}$} \\
\hline & Growth & 2 & 3 & 4 & Value & & & & & & \\
\hline Large & 0.75 & 0.84 & 0.82 & 0.70 & 0.66 & & & & & & \\
\hline 2 & 0.75 & 0.71 & 0.69 & 0.71 & 0.72 & & & & & & \\
\hline 3 & 0.72 & 0.67 & 0.70 & 0.68 & 0.74 & & & & & & \\
\hline 4 & 0.71 & 0.63 & 0.59 & 0.65 & 0.78 & & & & & & \\
\hline Micro & 0.71 & 0.73 & 0.67 & 0.73 & 0.79 & & & & & & \\
\hline \multicolumn{2}{|c|}{$G R S$} & 1.41 & & & & & & & & & \\
\hline \multicolumn{2}{|c|}{$D$-test, $\alpha_{i}=0$} & 30.44 & & & & & & & & & \\
\hline \multicolumn{2}{|c|}{$D$-test, $s_{i}=h_{i}=0$} & $22379.08^{* *}$ & & & & & & & & & \\
\hline
\end{tabular}


Finally, an examination of the intercept terms in Table 5 indicates that all portfolios have an insignificant estimate, with the exception of the portfolio micro-value. These estimates are lower than the estimates from the CAPM (see Table 4), suggesting that the pricing errors from the three factor model are lower. For example the average intercept term (using absolute values) for the portfolios in the large size quintile in 0.1 using the three factor model, while it is 0.26 using the CAPM. Results still indicate evidence of nonlinearity being present across size. This is demonstrated by the intercepts for the portfolios within the large size quintile being slightly negative. As size declines the average intercept decreases, with the lowest intercept values generally residing in size quintile 4 . The intercept terms then increase as size continues to decline with the largest average intercepts within the portfolios in the micro quintile.

The $G R S$ and $D$-statistic are both insignificant suggesting that we should not reject the null that the intercept terms are jointly equal to zero, and consequently that the three-factor model explains the time-series of portfolios well. The three-factor model explanatory power for each portfolio, as measured by adjusted $R^{2}$, is substantially higher than the comparative results from the CAPM. The average adjusted $R^{2}$ for the twentyfive equations is $71 \%$ which is a substantial increase over the CAPM which had an average of $54 \%$. This result indicates that not only does the three-factor model lead to smaller intercept estimates, it also explains a greater proportion of the variation in portfolio returns. This suggests that the three-factor model is the preferred model. More formally the $D$-statistic, which tests whether the estimates for $s$ and $h$ are jointly equal to zero, is strongly rejected indicating that the extra two factors play an important role in explaining the time-series variation in returns.

Results using the twenty-five portfolios indicate that the three-factor model provides additional explanatory power in explaining the time-series variation in returns when compared to the CAPM. Table 5 indicates that 
nearly all portfolios have significant loadings on the SMB, and HML factors. These results also indicate that the three-factor model leads to smaller intercept terms. This provides fairly conclusive evidence that the three-factor model is an improvement on the CAPM in explaining the time-series variation in portfolio returns.

\subsection{Cross-Sectional Regressions}

Table 6 presents the results from estimating Equations (10) and (11). These results allow us to assess whether the CAPM or the three-factor model explains the cross-sectional variation in expected returns. The base set of portfolios is again the 25 size and book-to-market sorted portfolios.

\section{Table 6}

\section{Cross-sectional tests of the CAPM and three-factor model}

Cross-sectional regression results from the CAPM and the three-factor model, using the excess returns of the size-book-to-market portfolios for the period January 1982 to December 2006. Panel A reports the results from the CAPM using the following moment conditions:

$E\left[r_{i t}\left(1-b_{M R P} M R P_{t}\right)\right]=0 \quad \forall i=1, \ldots, N$,

Panel B reports the results from the three-factor model using the following moment conditions:

$E\left[r_{i t}\left(1-b_{M R P} M R P_{t}-b_{S M B} S M B_{t}-b_{H M L} H M L_{t}\right)\right]=0 \quad \forall i=1, \ldots, N$.

Where $r_{i t}$ is the return on portfolio $i$ in month $t$ less the 13-week treasury note yield, $M R P_{t}$ is the valueweighted market monthly return less the 13 -week treasury note yield. $S M B_{t}$ is the return on the mimicking size portfolio and $H M L_{t}$ is the return on the mimicking book-to-market portfolio. The system is estimated using the GMM technique. A $J$-statistic is calculated which tests whether the pricing errors are jointly equal to zero.

** and $*$ denote significance at the $1 \%$ and $5 \%$ levels respectively.

\begin{tabular}{lccc}
\hline \multicolumn{4}{c}{ Panel A: CAPM } \\
& $\mathrm{b}_{\text {MRP }}$ \\
\hline Estimate & 2.71 \\
$t$-stat & $2.13^{*}$ \\
J-stat & $40.44^{*}$ \\
\multicolumn{4}{c}{} \\
\hline \multicolumn{4}{c}{ Panel B: Three-Factor Model } \\
& $\mathrm{b}_{\mathrm{MRP}}$ & $\mathrm{b}_{\mathrm{SMB}}$ & $\mathrm{b}_{\mathrm{HML}}$ \\
\hline Estimate & 6.43 & 5.73 & 17.48 \\
$t$-stat & $3.72^{* *}$ & $2.56^{*}$ & $8.61^{* *}$ \\
J-stat & 26.33 & & \\
\hline
\end{tabular}


The results from testing the CAPM are presented in Panel A of Table 6. These results demonstrate that there is a positive and significant estimate on the market risk premium. This implies that the market risk premium is a priced factor. Our results are similar with the Australian study of Durack, Durand \& Maller (2004). Durack, Durand \& Maller (2004) tested the cross-sectional implications of the CAPM in Australia over the time period 1981 to 2000 and found a positive, though insignificant, relationship between the market risk premium and returns.

The $J$-statistic tests whether the pricing errors are jointly equal to zero. Results from this test indicate that the null hypothesis should be rejected. This result is confirmation that the CAPM does not solely explain the cross-sectional variation in portfolios returns.

Turning to the cross-sectional test of the three-factor model, these results are reported in Panel B of Table 6. The results indicate that the market risk premium and the factors SMB and HML are priced, which is demonstrated by significant positive coefficients on these factors. The positive values on the $b_{i}$ estimates imply that there are positive risk premiums on the SMB, and HML factors.

Evidence from the USA indicates that only the HML factor is priced (Brennan, Wang \& Xia, 2004; Core, Guay \& Verdi, 2008; Parker \& Julliard, 2005; Petkova, 2006). However, these findings are in contrast to Durack, Durand \& Maller (2004) who found that only the SMB factor is priced in Australia over the time period 1990 to 2000. Durack, Durand \& Maller (2004) note that the insignificance of the HML factor may be due to their construction method. These differences include; using quarterly rather than monthly data, and perhaps more significantly, Durack, Durand \& Maller (2004) only had access to a small sample of 
stocks when constructing the HML factor. Naturally, covering a greater proportion of the market should lead to a better evaluation of the small and value premiums in Australia.

The results presented here indicate that both the HML factor and SMB factors are priced in Australia and indicate that the HML factor is highly significant in explaining the cross-section of portfolios returns.

The $J$-statistics of the three-factor model, which test whether the pricing errors are jointly equal to zero, indicate that the null hypothesis should not be rejected. That is, the pricing errors are insignificantly different from zero. This implies that the three-factor model can help explain the cross-sectional variation of portfolio returns.

\section{Conclusion}

While studies in overseas markets, particularly in the US market, have documented the significant influences of size and book-to-market effects on equity returns, equivalent research in the Australian market has failed to document similar findings. The Australian-based research has suffered from a severe limitation imposed by data availability with respect to both a limited coverage across listed stocks and an insufficient time period. Prior Australian research has also constructed size and book-market portfolios quite differently from US studies. This study remedies these problems by employing a new and specially constructed dataset

that provides coverage of over $98 \%$ of listed firms over the 25 year period of 1982 to 2006 , and by constructing portfolios using an alternate approach which is more consistent with approaches from the US market. 
In an initial examination of size and book-to-market effects, we document that the book-to-market effect is the dominant feature of the Australian market after independent portfolio sorts. That is, there is an insignificant difference in returns between large and small portfolios after controlling for book-to-market, and there is a significant difference in returns between high and low book-to-market portfolios after controlling for size. These results lead to the development of a set of mimicking portfolios that are designed to capture the premiums. We report average premiums on the various factors of SMB at $-0.22 \%$, HML at $0.76 \%$ and MRP at $0.51 \%$ per month. These magnitudes are generally consistent with prior evidence and the relatively high "value" premium is confirmed.

The factors are then tested across a range of portfolios in both time-series and in cross-section. The results reveal that all factors are significant in both the time-series and cross-sectional tests and that the premiums carry significant positive exposures. This is the first time that these factors have been consistently found to exhibit significant positive influences over Australian equity returns. In a series of comparative tests, the three-factor model is found to be consistently superior to the CAPM, although neither model can fully explain the time-series variation in portfolio returns.

This evidence is important for a number of reasons. First, the findings appear to settle the disputed question as to whether the value premium is indeed a positive and significant factor in the Australian market. Given the growing trend to utilize the three-factor model in asset pricing tests and in practical strategies of portfolio formation in the funds management industry, these findings provide direction. Second, the evidence continues the decline of the single factor model which has obvious implications for future research. This future research should include the added benefits of using a multifactor model to estimate cost of capital for firms. Third, the findings reveal variability in standard deviations and of the various sizes 
of the premiums across portfolios. These finding have implications for the economic significance of trading strategies based on size and value philosophies. Fourth, following Brailsford et al. (2011) and in contrast to prior Australian research, a portfolio construction method consistent with US studies is employed. Finally, the use of a clean and new dataset avoids criticisms of data snooping and hence the study adds to the comparative evidence across international equity markets. 


\section{References}

Bagella, M., L. Becchetti, and A. Carpentieri, 2000, "The first shall be last: Size and value strategy premia at the London Stock Exchange," Journal of Banking and Finance, 24, 893-919.

Banz, R.W., 1981, "The relationship between return and market value of common stocks," Journal of Financial Economics, 9, 3-18.

Barber, B. M., and J. D. Lyon, 1997, "Firm Size, Book-to-Market Ratio and Security Returns: A Holdout Sample of Financial Firms," Journal of Finance, 52, 875-883.

Beedles, W.L., P. Dodd, and R.R. Officer, 1988, "Regularities in Australian Share Returns," Australian Journal of Management, 13, 1-29.

Black, F., 1993a, "Beta and Return," Journal of Portfolio Management, 20, 8-18.

Black, F., 1993b, "Estimating Expected Return," Financial Analysts Journal, 49, 36-38.

Black, F., M.C. Jensen and M. Scholes, 1972, "The Capital Asset Pricing Model: Some Empirical Tests," in Michael C Jensen (ed.), Studies in the Theory of Capital Markets, Praeger.

Brailsford, T., C. Gaunt and M. O'Brien, 2011, “The Investment Value of the Value Premium”, Pacific Basin Finance Journal, forthcoming.

Brennan, M., A. Wang and Y. Xia, 2004, "Estimation and test of a simple model of intertemporal capital asset pricing," Journal of Finance, 59, 1743-1775.

Brown, P., D.B. Keim, A.W. Kleidon and T.A. Marsh, 1983, "Stock Return Seasonalities and the Tax-Loss Selling Hypothesis," Journal of Financial Economics, 12, 105-127.

Brown, P., A.W. Kleidon, and T.A. Marsh, 1983, "New evidence on the nature of size-related anomalies in stock prices," Journal of Financial Economics, 12, 33-56.

Chui, A.C., and K.J. Wei, 1998, "Book-to-market, firm size and the turn of the year effect: Evidence from Pacific-Basin emerging markets," Pacific Basin Finance Journal, 59, 275-293.

Cochrane, J. H., 2005, Asset Pricing, Princeton University Press, revised edition.

Core, J.E., W.R. Guay, and R. Verdi, 2008, "Is Accurals Quality a Priced Factor," Journal of Accounting and Economics, In press.

Daniel, K., and S. Titman, 1997, "Evidence on the Characteristics of Cross-Sectional Variation in Stock Returns," Journal of Finance, 52, 1-33.

Daniel, K., S. Titman, and K. J. Wei, 2001, "Explaining the Cross-Section of Stock Returns in Japan: Factors or Characteristics?" Journal of Finance, 56, 743-766. 
Davis, J.L., E.F. Fama, and K.R. French, 2000, "Characteristics, Covariances and Average Returns: 1929 to 1997," Journal of Finance, 55, 389-406.

Dimson, E., and P. Marsh, 1999, "Murphy's Law and Market Anomalies," Journal of Portfolio Management, 25, 53-69.

Durack, N., R.B. Durand, and R.A. Maller, 2004, "A best choice among asset pricing models? The Conditional Capital Asset Pricing Model in Australia," Accounting and Finance, 44, 139-162.

Durand, R.B., A. Juricev, and G.W. Smith, 2007, "SMB - Arousal, disproportionate reaction and the sizepremium," Pacific-Basin Finance Journal, 15, 315-328.

Durand, R.B., M. Limkriangkrai, and G.W. Smith, 2006, "In America's thrall: the effects of the US market and US security characteristics on Australian stock returns," Accounting and Finance, 46, 577-605.

Elfakhani, S., L.J. Lockwood, and T.S. Zaher, 1998, "Small Firm and Value Effects in the Canadian Stock Market," Journal of Financial Research, 21, 277-291.

Faff, R.W., 2001, "An examination of the Fama and French three-factor model using commercial available factors," Australian Journal of Management, 26, 1-17.

Faff, R.W., 2004, "A simple test of the Fama and French model using daily data: Australian evidence," Applied Financial Economics, 14, 83-92.

Fama, E.F., and K.R. French, 1992, "The Cross-Section of Expected Stock Returns," Journal of Finance, 47, 427-465.

Fama, E.F., and K.R. French, 1993, "Common risk factors in the returns on stocks and bonds," Journal of Financial Economics, 33, 3-56.

Fama, E.F., and K.R. French, 1996, "Multifactor Explanations of Asset Pricing Anomalies," Journal of Finance, 51, 55-84.

Fama, E.F., and K.R. French, 1998, "Value verses Growth: The International evidence," Journal of Finance, 53, 1975-1999.

Fama, E.F., and K.R. French, 2006, "The Value Premium and the CAPM," Journal of Finance, 61, 21632185.

Fama, E.F., and K.R. French, 2008, “Dissecting Anomalies," Journal of Finance, 63, 1653-1678.

Gaunt, C., 2004, "Size and Book-to-market effects and the Fama French three factor asset pricing model: Evidence from the Australian stockmarket," Accounting and Finance, 44, 27-44. 
Gharghori, P., H. Chan, and R.W. Faff, 2006, "Factors or Characteristics?: That is the Question," Pacific Accounting Review, 18, 21-46.

Gharghori, P., H. Chan, and R.W. Faff, 2007, "Are the Fama-French Factors Proxying Default Risk," Australian Journal of Management, 32, 223-250.

Gharghori, P., S. Stryjkowski, and M. Veeraraghavan, 2007, "Value versus Growth: Australian Evidence," Working Paper, Monash University.

Gibbons, M.R., S.A. Ross, and J. Shanken, 1989, "A test of the Efficiency of a given Portfolio," Econometrica, 57, 1121-1152.

Griffin, J. M., 2002, "Are the Fama and French Factors Global or Country Specific?," Review of Financial Studies, 15, 783-803.

Halliwell, J., R. Heaney, and J. Sawicki, 1999, "Size and Book-to-market effects in Australian Share Markets: A Time Series Analysis," Accounting Research Journal, 12, 122-137.

Haugen, R. A., and N. L. Baker, 1996, "Commonality in the determinants of expected stock returns," Journal of Financial Economics, 41, 401-439.

Henderson, S., G. Peirson, and K. Herbohn, 2008, Issues in Financial Accounting. Pearson Education Australia, Sydney.

Horowitz, J., T. Loughran, and N. Savin, 2000a, "The Disappearing Size Effect," Research in Economics, 54, 83-100.

Horowitz, J., T. Loughran, and N. Savin, 2000b, "Three Analyses of the Firm Size Premium," Journal of Empirical Finance, 7, 143-153.

Kothari, S., J. Shanken, and R.G. Sloan, 1995, "Another Look at the Cross-section of Expected Stock Returns," Journal of Finance, 50, 185-224.

Lakonishok, J., A. Shleifer, and R.W. Vishny, 1994, "Contrarian Investment, Extrapolation, and Risk," Journal of Finance, 49, 1541-1578.

LaPorta, R., J. Lakonishok, A. Shleifer, and R.W. Vishny, 1997, "Good news for value stocks: further evidence on market efficiency," Journal of Finance, 52, 859-874.

Loughran, T., 1997 "Book-to-Market across Firm Size, Exchange, and Seasonality: Is There an Effect," Journal of Financial and Quantitative Analysis, 32, 249-268.

Newey, W.K., and K.D. West, 1987, "Hypothesis Testing with Efficient Method of Moments," International Economic Review, 28, 777-787. 
Parker, J.A., and C. Julliard, 2005, "Consumption Risk and the Cross Section of Expected Returns," Journal of Political Economy, 113, 185-222.

Petkova, R., 2006, "Do the Fama-French Factors Proxy for Innovations in Predictive Variables," Journal of Finance, 61, 581-612. 